\title{
PEMBELAJARAN BERNYANYI MENGGUNAKAN METODE SIGHT READING
}

\author{
Prasetya Adi Gunawan ${ }^{1}$, Eko Raharjo ${ }^{2}$, \\ ${ }^{1}$ Mahasiswa Jurusan Sendratasik Universitas Negeri Semarang Indonesia \\ ${ }^{2}$ Dosen Jurusan Sendratasik Universitas Negeri Semarang Indonesia \\ Pendidikan Seni Musik, Universitas Negeri Semarang \\ Email : adi.gunawan46@yahoo.com
}

\begin{abstract}
Abstrak: Penelitian ini bertujuan untuk mengetahui dan mendeskripsikan tentang pembelajaran metode sight reading di SMP Negeri 30 Semarang. Manfaat dari penelitian ini secara teoritis adalah dapat meningkatkan prestasi dalam bidang bernyanyi dan secara praktis dapat meningkatkan pengetahuan tentang metode sight reading bagi siswa, guru, sekolah, dan peneliti. Teknik pengumpulan data dilakukan dengan teknik observasi, dan dokumentasi. Metode keabsahan data menggunakan triangulasi data. Teknik analisis data dilakukan meluali pengumpulan data, penyajian data, reduksi data, dan penarikan kesimpulan. Hasil penelitian ini adalah sebagai berikut : proses pelaksanaan pembelajaran terdiri dari pendahuluan yang terdiri dari mengkondisikan suasana kelas, apersepsi, dan menyampaikan tujuan pembelajaran. Kegiatan ini terdiri dari tahapan metode sight reading yaitu Mengamati materi, mencoba, dan proses kegiatan. Kegiatan penutup meliputi diskusi dengan siswa terhadap proses pembelajaran metode sight reading. Kemudian evaluasi atau penelian meliputi 2 aspek yaitu evaluasi yang dilakukan oleh ketrampilan, dan sikap.
\end{abstract}

Kata kunci: pembelajaran bernyanyi, sight reading

\section{PENDAHULUAN}

Pelajaran Seni Musik di SMP N 30 Semarang adalah salah satu mata pelajaran yang masuk dalam kurikulum pendidikan. Pelajaran ini diberikan kepada siswa kelas 7, 8, dan 9. Pentingnya pendidikan seni di sekolah menjadi salah satu aspek yang diperhitungkan oleh pemerintah. Pendidikan seni dapat digunakan sebagai sarana untuk membantu menyiapkan anak untuk kreatif, inovatif, dan mempunyai kepekaan yang tinggi. Dengan seni kita belajar kreatif dan berbagai hal lain yang dapat mengasah kemampuan keterampilan kita. Seni merupakan suatu keindahan 2 dan dalam paradigma pendidikan seni, terkandung pula tujuan pendidikan keseluruhannya, demikian juga hal itu berlaku untuk pendidikan seni musik

Upaya pemerintah untuk memajukan pendidikan terlihat melalui Undang-Undang No.20 tahun 2003 tentang Sistem Pendidikan Nasional (Sisdiknas) pasal 1, pendidikan merupakan usaha sadar dan terencana untuk mewujudkan suasana belajar dan proses pembelajaran agar peserta didik secara aktif mengembangkan potensi dirinya untuk memiliki kekuatan spiritual keagamaan, pengendalian diri, kepribadian, kecerdasan, akhlak mulia, serta keterampilan yang diperlukan dirinya, masyarakat, bangsa dan negara.

Pembelajaran seni musik di sekolah dapat memberikan kontribusi positif 
kepada siswa dalam memperoleh pengetahuan dan kemampuan dasar untuk mendengar, meragakan, berkreativitas dan berolah music secara langsung. Guna memperoleh pengetahuan dan kemampuan yang dimaksud, maka pembelajaran seni musik dilakukan dengan terprogram dan berencana agar tujuan dari pendidikan seni khususnya seni musik tercapai maksimal.

Pentingnya penggunaan metode pembelajaran seni musik di sekolah yaitu agar penyampaian materi yang diberikan guru mudah dimengerti oleh siswa dan untuk meningkatkan kemampuan siswa dalam pembelajaran seni musik. Untuk itu guru sebagai mediator dalam proses pembelajaran musik dituntut mampu menguasai materi yang diajarkan, mampu menggunakan metode yang tepat, mampu menggunakan langkah-langkah yang tepat dalam pembelajaran musik, mampu menggunakan media atau alat peraga sesuai pokok bahasan, mampu mengelola kelas serta dapat menggunakan waktu yang tersedia dengan tepat. Dengan demikian, dalam merencanakan proses belajar mengajar, seorang guru dituntut untuk dapat menentukan langkah-langkah yang sistematis dan efektif.

Tujuan pembelajaran adalah tujuan yang ingin dicapai oleh kegiatan pembelajaran. Tujuan pembelajarn adalah agar siswa mencapai perkembangan optimal dalam ketiga aspek tersebut. ( TIM MKDK IKIP Semarang, 1996:12). Tujuan pembelajaran disesuaikan dengan tujuan pendidikan nasional yang dinyatakan ada pasal 3 UU No. 20 tahun 2003, yakni: "Berkembangnya potensi peserta didik agar menjadi manusia yang beriman dan bertakwa kepada Tuhan Yang Maha Esa, berahlak mulia, sehat, berilmu, cakap, kreatif, mandiri, dan menjadi warga Negara yang demokratis serta bertanggung jawab" (Sani,2014:45).

Metode adalah cara yang berfungsi sebagai alat untuk mencapai tujuan (Siswoyo, 2007: 133), sedangkan menurut
Ekosusilo (1986: 15) metode merupakan cara membimbing pemakainya untuk mencapai suatu tujuan. Dalam Kamus Besar Bahasa Indonesia (Poerwadharmita, 1986: 649) metode adalah cara yang telah teratur dan terpikir baik- baik untuk mencapai sesuatu maksud. Sight reading adalah kesanggupan untuk membaca sekaligus memainkan notasi yang belum dikenal sebelumnya (khodijat, 1984: 10). Sight reading adalah memainkan atau menyanyikan dalam pertama kali baca Banoe (2003: 379). Pendapat lain diungkapkan oleh Syaffiq (2003:274) bahwa cara memainkan alat musik atau menyanyikan lagu dengan partitur yang baru dilihat pada saat itu juga dikenal dengan Sight reading.

Berkaitan hal tersebut maka dilakukan penelitian yang bertujuan untuk mengetahui dan mendeskripsikan pembelajaran bernyanyi menggunakan metode sight reading pada siswa SMP N 30 Semarang.

\section{METODE PENELITIAN}

Penelitian ini menggunakan metode Sight Reading dengan metode penelitian Kualitatif. Dalam penelitian ini penulis melakukan penelitian mengenai pembelajaran bernyanyi menggunakan metode Sight Reading kepada siswa kelas 8 di SMPN 30 Semarang. Peneliti meneliti bagaimana hasil dari proses pembelajaran bernyanyi dengan menggunakan metode Sight Reading pada siswa di SMPN 30 Semarang.

sering disebut $\begin{gathered}\text { Metode } \\ \text { metode }\end{gathered}$ penelitian naturalistik karena penelitiannya dilakukan pada kondisi yang alamiah. Penelitian dilakukan pada obyek yang alamiah. Obyek yang alamiah adalah obyek yang berkembang apa adanya, tidak dimanipulasi oleh peneliti dan kehadiran peneliti tidak begitu mempengaruhi dinamika pada obyek tersebut. Metode penelitian kualitatif menurut Sugiyono (2013:15) adalah metode penelitian 
yang berdasarkan filsafat postpositivisme, digunakan untuk meneliti pada obyek yang alamiah, (sebagai lawannya adalah eksperimen) dimana peneliti adalah sebagai instrument kunci, pengambilan sampel sumber data dilakukan secara purposive dan snowball, teknik pengumpulan dengan trianggulasi (gabungan), analisis data bersifat induktif/ kualitatif, dan hasil penelitian kualitatif lebih menekankan makna dari pada generalisasi.

Peneliti menggunakan jenis penelitian deskriptif kualitatif karena peneliti ingin mendeskripsikan bagaimana penerapan metode sight reading dalam pembelajaran bernyanyi padasiswa kelas 8 di SMP Negeri 30 Semarang. Dalam hal ini yang akan diteliti adalah Metode Sight Reading yang diterapkan pada pembelajaran bernyanyi pada siswa di SMP Negeri 30 Semarang.

Penelitian ini dilakukan di SMP Negeri 30 Semarang. Sasaran dari penelitian ini adalah pembelajaran metode sight reading di SMP Negeri 30 Semarang, meliputi data siswa, perencanaan pembelajaran, pelaksanaan pembelajaran, evaluasi pembelajaran, hasil pembelajaran.

Data atau informasi yang diperlukan diambil dengan menentukan sumber data atau informasi yang terdiri dari subjek data dan objek data. Subjek data dari penelitian ini adalah siswa kelas 8 SMP Negeri 30 Semarang. Hal ini dikarenakan siswa merupakan pihak yang terlibat/mengalami langsung dan saling mendukung terlaksananya proses pembelajaran dan agar hasil belajar siswa bisa baik dengan menggunakan metode sight reading pada pembelajaran musik di SMP Negeri 30 Semarang.

Objek data dari penelitian ini adalah informasi yang diperoleh dari subjek penelitian. Objek penelitian ini adalah kegiatan-kegiatan yang merupakan bentuk dari penerapan metode sight reading pada pembelajaran musik di SMP Negeri 30 Semarang serta berbagai bentuk dukungan yang diberikan untuk memperlancar proses pembelajaran tersebut.

Adapun teknik penelitian pada penelitian ini yaitu: (1) Observasi yaitu suatu proses yang kompleks, suatu proses yang tersusun dari berbagai proses biologis dan psikologis, dua diantara yang terpenting adalah proses pengamatan dan ingatan. Hal-hal yang akan diobservasi dalam penelitian adalah siswa SMP Negeri 30 Semarang yang mendapatkan materi seni musik, kemudian materi ajar dan proses pembelajaran seni musik yang diberikan peneliti kepada siswa SMP Negeri 30 Semarang. (2) Wawancara menurut Maleong (dalam Sumaryanto, 2014:39) adalah percakapan dengan maksud tertentu. Percakapan tersebut dilakukan oleh dua pihak, yaitu antara pewawancara yang memberikan pertanyaan dan yang diwawancarai yang menjawab pertanyaan. Narasumber dalam penelitian ini adalah guru seni budaya (seni musik) dan siswa kelas VIII SMP Negeri 30 Semarang. Materi dari wawancara ini adalah bagaimana proses pembelajaran musik terlaksana di SMP Negeri 30 Semarang. (3) studi dokumentasi dalam penelitian ini dilakukan untuk memperoleh data mengenai perencanaan pembelajaran dan proses pelaksanaan pembelajaran musik di SMP Negeri 30 Semarang. Studi dokumentasi mengenai pelaksanaan pembelajaran bertujuan untuk memperoleh dokumen berupa gambargambar saat berlangsungnya proses pembelajaran. Selain data mengenai proses pembelajaran, data mengenai lokasi sekolah, jumlah guru, dan jumlah siswa juga diambil pada studi dokumentasi ini.

Metode pemeriksaan keabsahan data dilakukan dengan triangulasi Triangulasi dilakukan dengan tiga cara, yaitu: (1) Triangulasi sumber adalah keabsahan data dengan mengacu beberapa sumber merupakan pengecekan derajad data yang diperoleh berdasarkan fakta di lapangan, (2) Triangulasi teknik untuk menguji kredibilitas data 
dilakukan dengan cara mengecek data kepada sumber yang sama dengan teknik yang berbeda, (3) triangulasi waktu untuk menguji kredibilitas data dilakukan dengan cara melakukan pengecekan dengan wawancara, observasi atau teknik lain dalam waktu dan situasi yang berbeda.

Teknik analisis data dilakukan dengan reduksi data, penyajian data, dan menarik kesimpulan. Mereduksi data adalah berarti merangkum, memilih halhal yang pokok, memfokuskan pada halhal yang penting, dicari tema dan polanya dan membuang yang tidak perlu (Sugiyono, 2013:338). Dalam penelitian kualitatif penyajian data dapat dilakukan dalam bentuk uraian singkat, bagan dan hubungan antar kategori, flowchart dan sejenisnya. Dengan penyajian data, maka data terorganisasikan, tersusun dalam pola hubungan, sehinggan akanmudah dipahami. Kesimpulan dalam penelitian kualitatif yang diharapkan adalah merupakan temuan baru yang sebelumnya belum pernah ada.

\section{HASIL PENELITIAN DAN PEM- BAHASAN}

\section{Hasil Penelitian}

Metode sight reading memiliki peran yang cukup besar pada pembelajaran bernyayi di sekolah. Metode sight reading memiliki prosedur atau langkah-langkah ilmiah yang diterapkan dalam pembelajaran, hal ini bisa membuat siswa semakin mandiri dalam pembelajaran dan mampu membuat kreatifitas siswa dalam pembelajaran meningkat. Tujuan dari pembelajaran tidak hanya menjadikan siswa berkembang dalam aspek kognitif saja, melainkan juga berkembang dalam aspek afektif dan psikomotorik. Pembelajaran dengan menggunakan metode sight reading tidak hanya mengembangakan aspek kognitif, afektif, dan psikomotor saja, kualitas lain yang dikembangkan dan harus terealisasikan dalam proses pembelajaran antara lain kreativitas, kemandirian, kerja sama, solidaritas, kepemimpinan, empati, toleransi dan kecakapan hidup peserta didik guna membentuk watak yang baik. Untuk mencapai kualitas dalam kegiatan pembelajaran perlu menggunakan prinsip yang sesuai dengan metode sight reading yaitu (1) pembelajaran berpusat pada peserta didik, (2) mengembangkan kreativitas peserta didik, (3) menciptakan kondisi menyenangkan dan menantang, (4) bermuatan nilai etika, estetika, logika, dan kinestetika, dan (5) menyediakan pengalaman belajar (learning experience) yang beragam melalui penetapan berbagai strategi dan metode pembelajaran yang menyenangkan, kontekstual, efektif, efisien, dan bermakna.

Penerapan metode sight reading dalam pembelajaran bernyanyi terbagi menjadi 5 tahapan yaitu (1) mengamati lagu dengan cara siswa mendengarkan dan memperhatikan lagu yang diberikan peneliti (2) peneliti memberikan materi pembelajaran dengan menggunakan metode sight reading kepada siswa, (3) siswa menyanyikan lagu sesuai dengan materi yang telah diberikan oleh peneliti, (4) peneliti memberikan penilaian terhadap hasil pembelajaran dengan metode sight reading, (5) evaluasi pembelajaran.

Kegiatan pendahuluan bertujuan untuk menciptakan suasana awal pembelajaran yang efektif dan menyenangkan yang memungkinkan siswa dapat mengikuti pembelajaran dengan baik (Hosnan, 2014: 142).

\section{Pembahasan}

kegiatan pendahuluan yang dilakukan oleh peneliti sesuai dengan RPP yang telah dibuat antara lain peneliti mengkondisikan susasana belajar dengan saling memberi salam dan berdoa, kemudian apersepsi sebagai pengantar materi pemberian motivasi oleh peneliti sebelum masuk ke kegiatan inti pembelajaran, dan menyampaikan tujuan pembelajaran. Pada kegiatan pendahuluan, setiap peneliti 
mengkondisikan suasana pembelajaran pada awal pertemuan di kelas. Pengkondisian suasana pembelajaran atau pengkondisian yang pertama dilakukan adalah saling memberi salam baik dari siswa maupun dari peneliti. Hal ini dilakukan agar hubungan antara peneliti baik dan ada rasa saling menghormati. Kemudian berdoa sebagai pengantar pembelajaran agar dalam berlangsungnya pembelajaran lancar dari awal hingga akhir pembelajaran. Setelah berdoa peneliti mempresensi kehadiran siswa guna kelengkapan administrasi sekolah supaya mengetahui siapa yang tidak berangkat beserta alasannya.

Peneliti menjelaskan apa tujuan pembelajaran pada awal pertemuan kepada siswa karena dapat memberi gambaran akan materi yang dicapai selama pembelajaran. Tujuan pembelajaran berkaitan dengan pembelajaran metode sight reading. Berdasarkan hasil observasi, penjelasan mengenai tujuan pembelajaran dilakukan pada setiap pertemuan. Peneliti menyampikan tujuan pada pertemuan saat itu, tujuan tersebut antara lain (1) menerima, menanggapi, dan mengahargai keragaman dan keunikan musik di Indonesia sebagai anugerah Tuhan dengan baik, (2) menunjukan sikap menghargai, jujur, dan disiplin melalui aktivitas berkesinian, (3) menunjukan sikap percaya diri motivasi internal dan kepedulian terhadap lingkungan dalam berkarya seni, (4) memahami pengertian metode sight reading, dan mengidentifikasikan dan mempraktekan metode sight reading dalam bernyayi.

Berdasarkan hasil observasi dan dokumentasi, peneliti lebih menonjolkan tahapan metode sight reading pada kegiatan inti meliputi kegiatan mengamati materi, bernyanyi dan evaluasi. Kegiatan yang dilakukan siswa yang pertama adalah mengamati. Kegiatan mengamati merupakan salah satu strategi pembelajaran yang menggunakan media asli dalam rangka membelajarkan siswa yang mengutamakan kebermaknaan proses belajar. Metode observasi mengedepankan pengamatan langsung objek yang akan dipelajari sehingga siswa mendapatkan fakta berbentuk data yang objektif yang kemudian dianalisis sesuai tingkat perkembangan siswa (Hosnan, 2014: 39). Dalam tahapan ini siswa diberikan secara langsung pembelajaran penjelasan materi metode sight reading. Peneliti memfasilitasi siswa dengan pengalaman langsung melaui media audio visual atau secara langsung diberikan oleh peneliti. Hal ini bertujuan untuk mengasah kemampuan siswa dalam mengkaji sebuah pengetahuan yang baru mereka dapat atau permasalahan yang mereka hadapi.

Kegiatan setelah mengamati dan pemberian materi adalah praktek. Untuk memperoleh hasil belajar yang nyata atau otentik, peserta didik harus mencoba atau melakukan percobaan, terutama untuk materi atau substansi yang sesuai. Menurut Syaiful Bahri Djamarah (dalam Hosnan, 2014: 58), metode eksperimen adalah cara penyajian pelajaran di mana siswa melakukan percobaan dengan mengalami dan membuktikan sendiri sesuatu yang dipelajari.

Dalam pembelajaran lagu daerah ini siswa diminta untuk menyanyikan lagu daerah secara individu dengan menggunakan metode sight reading yang baik dan benar. Dalam pelaksanaannya, siswa belajar tahap demi tahap, maka dari itu peneliti membagi materi pembelajaran menjadi 4 kali pertemuan. Tahapan mencoba ini dibagi menjadi 4 pertemuan untuk mendapatkan hasil pembelajaran. Peneliti melakukan observasi yang dimulai dari pertemuan pertama.

1) Proses Satu

Observasi yang pertama dilakukan di kelas VIIIA,VIIIB dan VIIIC. Kegiatan yang dilakukan pada awal pertemuan pertama adalah siswa mencoba bernyanyi langsung lagu daerah dengan pemberian partitur yang diberikan oleh peneliti. Kegiatan bernyanyi dimulai pada 
pertemuan pertama, siswa mencoba secara langsung bernyanyi yang di perhatikan oleh peneliti. Siswa diminta untuk maju mencoba langsung bernyanyi dengan partitur lagu daerah Oulate, dan peneliti melihat bagaimana kreasi dan hasil bernyayi siswa dalam lagu tersebut. Tahapan ini peneliti bertujuan untuk melihat kemampuan siswa dalam bernyanyi dengan membaca partitur secara langsung.

\section{2) Proses Dua}

Observasi selanjutnya dilakukan di kelas yang sama seperti kasus pertama, yaitu kelas VIIIA, VIIIB, dan VIIIC. Pertemuan kedua dilakukan pemberian materi lagu oleh peneliti kepada siswa.Pada kegiatan ini dimulai pada pertemuan kedua,peneliti memberikan materi lagu-lagu daerah. Adapun aspek materi tersebut mengenai lagu daerah yaitu : pengertian bernyanyi, pengertian lagu daerah, makna lagu daerah, fungsi lagu daerah, dan ciri-ciri lagu dareah. Penjelasan materi tersebut adalah. Pengertian bernyanyi adalah aktivitas yang sering dilakukan oleh manusia, melalui aktivitas ini manusia dapat mengungkapkan perasaan melalui nada dan irama serta kata-kata. Ada yang dilakukan secara unisono tetapi juga ada yang dilakukan dengan membentuk vokal group.

\section{3) Proses Tiga}

Observasi selanjutnya dilakukan di kelas yang sama yaitu kelas VIIIA, VIIIB, dan VIIIC. Pertemuan ketiga dilakukan peneliti untuk memberikan contoh dan teknik-teknik dalam bernyanyi. Peneliti mempraktekan cara bernyayi dalam bentuk pemanasan untuk melatih bernyayi siswa. Teknik bernyanyi tersebut antara lain sikap badan, pernafasan, intonasi, dan artikulasi. Pemanasan dilakukan dengan sikap badan tegak dan menyanyikan notasi yang dibunyikan oleh peneliti melalui media keybord. Notasi yang diberikan oleh peneliti dengan kata "ma" dalam satu nafas. Pemanasan ini juga sekaligus melatih artikulasi dalam bernyanyi. Dalam tahapan pemanasan dilakukan supaya siswa mengetahui dan bisa bernyanyi lagu daerah. Setelah melakukan pemanasan, siswa diberikan materi lagu daerah yang sudah disiapkan oleh peneliti. Lagu pada materi ini adalah lagu "Oulate".

\section{4) Proses Empat}

Pertemuan keempat digunakan peneliti untuk pengambilan data untuk salah satu sumber penilaian dari hasil pembelajaran yang telah dilakukan. Dalam kegiatan ini peneliti meminta siswa untuk menyanyikan lagu Oulate secara individu yang diiringi menggunakan keybord dengan materi yang sesuai seperti yang telah dijelaskan di pertemuan sebelumnya oleh materi kepada siswa. Siswa diminta untuk maju kedepan satu persatu untuk mengetahui hasil pembelajaran siswa dari pertemuan sebelumnya. Disaat salah satu siswa mempraktekkan kedepan untuk bernyanyi, siswa lainnya diminta untuk memperhatikan siswa yang sedang bernyayi didepan kelas.

Kegiatan penutup meliputi peneliti bersama-sama dengan siswa saling berdiskusi dengan hasil pembelajaran menggunakan metode sight reading, melakukan penilaian atau refleksi secara singkat terhadap kegiatan yang sudah dilaksanakan secara konsisten dan terprogram. Setelah selesai semua peneliti menutup pelajaran dengan mengucapkan salam.

Evaluasi atau penilaian pembelajar yang dilakukan oleh peneliti dibagi menjadi 2 aspek, yaitu aspek ketrampilan dan aspek sikap. Penjelasan dari kedua aspek tersebut sebagai berikut. Evaluasi keterampilan siswa meliputi penilaian proses, penilaian produk, penilaian proyek, dan penilaian portofolio. Pada pembelajaran bernyanyi dengan metode sight reading, penilaian keterampilan hanya penilaian proses. Penilaian proses dilakukan selama pembelajaran musik berlangsung. Disini peneliti melihat perkembangan siswa dari pertemuan ke pertemuan apakah ada kemajuan atau tidak. Penilaian proses dilakukan dengan 
menilai penyajian bernyanyi dari setiap siswa yang telah mengikuti proses pembelajaran pada pertemuan pertama hingga pertemuan keempat. Dari penampilan bernyanyi setiap siswa peneliti dapat melihat siswa itu paham dan mengerti atau tidak dengan pembelajaran metode sight reading.

Penilaian sikap berhubungan dengan bagaimana perilaku dan kedisiplinan siswa dalam mengikuti pembelajaran bernyanyi. Penilaian sikap meliputi penilaian diri sendiri, penilaian antar teman, dam observasi. Dalam pembelajaran ini peneliti menggunakan penilaian observasi yaitu penilaian yang dilakukan oleh peneliti yang bertujuan untuk menilai sikap dan perilaku siswa selama mengikuti pelajaran seni dan dilakukan setiap pelajaran. Peneliti melakukan observasi dengan mengamati secara seksama siswa dalam mengikuti pelajaran. Selain itu peneliti juga memberikan evaluasi mengenai keseluruhan kegiatan pembelajaran yang dilakukan oleh siswa, memberikan solusi jika terjadi kesulitan selama berlangsungnya proses belajar siswa. Dalam proses pembelajaran menggunakan metode sight reading sikap siswa terlihat sangat antusias dan aktif, dengan adanya minat para siswa untuk belajar menggunakan metode tersebut, disaat proses pembelajaran para siswa sangat senang dan semangat untuk mengikuti belajar bernyanyi. Dengan bukti pada proses pembelajaran yang keempat dimana pada saat praktek bernyanyi siswa ingin sekali untuk menyanyikan lagu tersebut setelah materi materi mengenai lagu daerah dan metode sight reading telah disampaikan.

Dari hasil penilaian menunjukkan bahwa metode sight reading sangat diminati oleh siswa, dimana hasil dari penilaian menunjukkan adanya perbedaan hasil bernyanyi sebelum pemberian materi dan sesudah pemberian materi metode sight reading. Sebelum pemberian materi siswa masih kebingungan dalam membaca notasi angka sebuah lagu sehingga hasil bernyanyi siswa kurang baik, berbeda setelah diberikan materi pembelajaran metode sight reading siswa mampu bernyanyi dengan baik dan bisa membaca notasi angka sebuah lagu.

\section{SIMPULAN}

Tahapan kegiatan inti pembelajaran bernyanyi menonjolkan pembelajaran menggunakan metode sight reading, tahapan tersebut adalah

1. Tahapan mengamati materi dilakukan oleh peneliti kepada siswa pada pertemuan kedua dan pertemuan ketiga. Siswa memperhatikan peneliti yang memberikan contoh teknik vokal yang baik melalui pemanasan dan menyanyikan lagu Oulate.

2. Tahapan mencoba yaitu pada pertemuan pertama dan keempat,pada pertemuan pertama siswa mencoba menyayikan lagu Oulate secara langsung tanpa pemberian materi oleh peneliti, tujuannya untuk mengetahui kemampuan dasar masing-masing siswa dan pada pertemuan keempat siswa mencoba kembali menyanyikan lagu stelah diberikan semua materi mengenai pembelajaran sight reading.

3. Tahapan terakhir yaitu evaluasi dan penilaian, tahapan ini dilakukan untuk mengetahui hasil pembelajaran menggunakan metode sight reading, dari hasil penelitian yang dilakukan menunjukkan bahwa adanya perbedaan kualitas dan cara bernyanyi siswa sebelum dan sesudah pemberian materi metode sight reading. Hasil bernyanyi siswa jauh lebih baik setelah peneliti memberikan materi metode sight reading dibandingkan sebelum diberikan materi tersebut. 
SARAN

\section{References}

Arikunto, Suharisni. 2006. Prosedur Penelitian Suatu Pendekatan Praktek. Jakarta: Rineka Cipta.

Azwar, Saifuddin. 2014. Metode Penelitian. Yogyakarta: Pustaka Pelajar.

Ekosusilo, Madya. 1986. Metodik Khusus Pengajaran Seni Musik Sekolah.

Semarang: Effhar Publishing.

Florentinus, Totok, S. 1997.

Pengembangan Instrumen Pengukuran Kemampuan Solfegio. Thesis Jakarta: IKIP Jakarta.

\begin{tabular}{|c|c|}
\hline & 2005. \\
\hline Penggunaan & Metode Solfegio \\
\hline Pembelajaran & Keterampilan \\
\hline
\end{tabular}

Hamdani. 2011. Strategi Belajar Mengajar. Bandung: CV. Pustaka Setia.

Hamalik,Oemar. 2012. Proses Belajar Mengajar. Jakarta: Bumi Aksara.

Hosnan. 2014. Pendekatan Saintifik dan Konstektual dalam Pembelajaran Abad 21. Bogor: Ghalia Indonesia.

Jamalus, 1988. Pengajaran Musik Melalui Pengalaman musik. Departemen Pendidikan dan Kebudayan: Jakarta.

Jeni Amriani, Tulus Handra Kadir dan Syahrel. 2013. "Pembelajaran Apresiasi Seni Musik Kelas 7 di SMP N 18 Padang". Vol 2 No 1.

Kennedy, M., 1985, The Concise Oxford Dictionary of Music, London: Oxford University Press.

Khodijat, Latifah. 1986. Istilah-istilah Musik. Jakarta: Depdiknas.

Peraturan Menteri Pendidikan Nasional (Permendiknas) Nomor 23 Tahun
2006.Tentang Standar Kompetensi Lulusan untuk Satuan Pendidikan Dasar dan Menegah, 2006. Jakarta: Kementrian Pendidikan Nasional.

Rifa'i, Achmad dan Catharina Tri Anni. 2009. Psikologi Pendidikan. Semarang:Universitas Negeri Semarang Press.

Sagala, Syaiful. 2013. Konsep dan Makna Pembelajaran. Bandung: Alfabeta.

Slameto. 2010. Belajar dan Faktor-faktor yang Mempengaruhi. Jakarta: Rineka Cipta.

Sudjana, Nana. 2009. Penilaian dan Hasil Proses Belajar Mengajar. Bandung: PT Remaja Rosdakarya.

Sugiyono. 2010. Metode Penelitian Kuantitatif Kualitatif dan $R \quad \& \quad D$. Bandung: Alfabeta.

Sulasmono, 2013. "Peningkatan kemampuan vokal melalui metode solfegio" Vol 13 No 1.

Suwarto, I. G. Harry, dkk. 2002. Seni Musik Untuk SLTP Kelas 2. Jakarta: Galaxy Mega Puspa.

Syaffiq, Muhammad. 2003. Ensiklopedia Musik klasik. Yogyakarta: Adicita karya Nusa.

Kristyana, L., \& Suharto, S. (2014). Singing as a Strategy to Enhance the Ability to Speak for Early Childhood. Harmonia: Journal Of Arts Research And Education, 14(2), 123-130. doi:http://dx.doi.org/10.15294/harmonia.v $14 \mathrm{i} 2.3293$

Sinaga, S. (2011). PEMANFAATAN DAN PENGEMBANGAN LAGU ANAKANAK DALAM PEMBELAJARAN TEMATIK PADA PENDIDIKAN ANAK USIA DINI / TK. Harmonia: Journal Of 
Arts Research And Education, 10(1). doi:http://dx.doi.org/10.15294/harmonia.v $10 \mathrm{i} 1.55$

Suharto, S.(1991). Bayangan Nada sebagai Materi Pembelajaran Musik Pemula. Media, 8 .

Suharto, S. Peran Seni dalam Pengoptimalan Fungsi Otak. Lingua Artistika, 23(3), 400-142
Sumaryanto, F. (2011). KEMAMPUAN MUSIKAL (MUSICAL ABILITY) DAN PENGARUHNYA TERHADAP PRESTASI BELAJAR MUSIK. Harmonia: Journal Of Arts Research And Education, $1(1)$. doi:http://dx.doi.org/10.15294/harmonia.v 1 i1.839 